\title{
Corporate Strategy Difference and Earnings Management Motivation
}

\author{
Lei Chen
}

\author{
School of Economics \& Management, Nanjing University of Science \& Technology, China \\ 454058066@qq.com
}

\begin{abstract}
To investigate the impact of corporate strategy differences on the value relevance of earnings management, the study use Chinese listed companies as a sample and find that the greater the degree to which a firm's strategy deviates from the industry's conventional model, the lower the value relevance of the discretionary accruals. This indicates that the greater the degree of strategic difference, the motivation of enterprises to engage in earnings management is more likely to be opportunistic rather than signal transmission. This research has some enlightening significance to identify the value relevance of earnings management.
\end{abstract}

Keywords: strategic differences; discretionary accrual; value relevance.

\section{Introduction}

Whether earnings management is beneficial to financial reporting users has been a controversial topic. Most of the prior researches viewed earnings management as a deliberate use of accounting policy choice and accounting estimates to mislead investors, so as to seek personal gains, and thus the earnings management will distort the true performance of enterprises, reduce the transparency of information. However, Watts and Zimmerman (1986) pointed out that earnings management can be used to exchange managers' private information or distort the report's earnings. Scott (2006) pointed out that the reason for the existence of earnings management is because it also has a favorable side, that is, earnings management may be the means to convey private information to the outside world. Since the 90s of last century, whether earnings management is beneficial to the enterprise, some empirical studies have examined the relationship between discretionary accruals and enterprise value, but come to inconsistent conclusions. Some studies have found that discretionary accrual is positively correlated with firm value (Subramanyam, 1996; Beaver and Engel, 1996; Louis and Robinson, 2003); however, more studies have found that there is no significant correlation or negative correlation between the discretionary accruals and firm value [1].

In recent years, the impact of corporate strategy on earnings quality has been a cause for concern. Bentley et al. (2013) provided empirical support for the strategic impact of earnings quality [2]. They use the US listed companies as a sample to study the relationship between the company's strategic positioning and financial reporting violations. The study found that the probabilities of corporate financial reporting violations using exploratory strategies are higher than those of defensive strategies. Although corporate strategy has been the focus of earnings management scholars, and existing research finds that corporate strategy affects earnings management decisions, few studies examine how corporate strategies affect earnings management motives and consequences

Based on the above analysis, we explore the value relevance of earnings management from the perspective of strategic differentiation, and try to find out whether and how the firm's strategic differentiation affects the relevance of earnings management. We examine the impact of strategic diversification on the value relevance of discretionary accruals, using Chinese listed companies from 2000 to 2014 as a sample. This study shows that the higher the degree of strategic difference, the greater the value relevance of discretionary accruals.

\section{Related Literatures and Research Question}

\subsection{Related Literatures}

Louis (2003) assumed that when managers are optimistic about corporate performance, companies tend to split the stock, at this time; discretionary accruals are used to transfer private information [3]. 
Teoh et al. (1998) found that opportunistic earnings management is carried out in stock issuance [4]. Fudenberg and Tirole (1995) devised an analytical model to estimate the earnings expectations of financial analysts (Degeorge et al., 1999) or to influence specific investors such as institutional investors (BuShee, 1998). The model expects managers to have the incentive to reduce the likelihood of being laid off by borrowing future earnings to increase current earnings when performance is poor. Francis et al. (2005) found that the comprehensive index of management and environmental factors (congenital size, cash flow, income standard deviation and the standard deviation of the business cycle and negative earnings frequency) account for most of the accrual quality [5]. This result suggests that if accruals play a role in their planned economic realities, they will, as expected, largely reflect the fundamentals of the economy - the business model and the business environment. Bowen et al. (2008) found that accounting judgments associated with lower corporate governance (measured in part by abnormal accruals) lead to better future financial performance [6].

\subsection{Hypothesis}

Previous studies have indicated that greater the extent to which the firm's strategy deviates from the industry's conventional model, the higher the degree of asymmetric information between the firm and external stakeholders (Carpenter, 2000) [7]. The reason is that the strategy determines the company's business model, deviation from the industry's conventional strategy usually leads to the company's business model is not familiar with the stakeholders, resulting in higher financing costs. Therefore, the managers of the extreme strategy companies have the motivation to convey the company's private information through information disclosure to alleviate the information asymmetry. Managers are reluctant to communicate in a more direct and explicit way, such as the news media, teleconferences, and so forth, due to agency costs and litigation risk (Skinner, 1997; Baginski et al. 2002) [8]. On the contrary, they prefer to adopt a subtler way of communicating private information, such as optimism or indications, to external stakeholders about the company's prospects for growth. Therefore, we expect companies with high strategic differences to have a motivation to engage in earnings management, which is designed to deliver proprietary information, given better corporate governance. In view of the value relevance of information driven earnings management, this leads to our hypothesis:

H1: The higher the degree of strategic differences, the higher the correlation between discretionary accrual and market value.

\section{Research Design}

\subsection{Sample Selection and Data Sources}

We take China 2000-2014 A-share listed companies as the initial research sample. From the existing studies, the following screening process is carried out. First, the financial listed companies are excluded. Secondly, in order to ensure the reliability of the calculation of the earnings management index, the industry with annual observations of less than 15 is eliminated. Thirdly, the companies with missing data are excluded. After the above screening, there are a total of 20116 firm-year observations. To reduce the effect of extreme values on the study results, we tailored all continuous variables at the $1 \%$ and $99 \%$ percentiles.

\subsection{Model Design}

The existing research models of earnings management attributes are different. However, the basic idea is that if the accruals are positively correlated with firm value or future cash flow, it is an information-driven earnings management; otherwise it is an opportunistic earnings management. We use Price as the dependent variable, DA and SD as the independent variables, and control the Age, $\mathrm{MB}$, and NI. In order to control the annual and industry fixed effects, we also add the annual and industry dummy variables as control variables. Referring to the research of Cohen et al (2011), in order to test the influence of strategic differences on earnings management motivation, we use the following regression model: 


$$
\begin{aligned}
\text { Price } & =\beta_{0}+\beta_{1} D A+\beta_{2} S D+\beta_{3} S D^{*} D A+\beta_{4} M B+\beta_{5} \text { Age } \\
& +\beta_{6} \text { Eps }+\beta_{7} \text { Growth }+\beta_{8} \text { Mature }+\beta_{9} \text { Decline } \\
& +\beta_{10} \text { Shakeout }+ \text { IND }+ \text { Year }+\varepsilon
\end{aligned}
$$

Where, Price is the year-end stock closing price, SD is the strategic difference, DA is the per-share accrual based on the revised Jones model, MB represents the ratio of market value to book value, Growth is the growth period of the enterprise life cycle, Mature is the life cycle maturity, Shakeout is the life cycle Decline indicates the decay of the life cycle, Age represents the age of the listing, IND and YEAR represent the industry and year, subscript $\mathrm{i}$ represents the company, and subscript $\mathrm{t}$ represents the year. If hypothesis 1 is valid, we expect the coefficients of SD*DA to be significantly positive.

\section{Results}

\subsection{Descriptive Statistics}

Table 1 shows the descriptive statistics of the main variables. The mean and median values of Price are 10.97 and 8.56, respectively. The maximum and minimum values are 47.85 and 1.03 , respectively, and the standard deviation is 8.27 , which indicates that the stock price of different companies is quite different. The maximum and minimum values of DA is 3.69 and -3.49 , respectively, and the standard deviation is 1.00 , indicating that there are significant differences in discretionary accruals between different sample companies.

TABLE 1. DESCRIPTIVE STATISTICS OF VARIABLES.

\begin{tabular}{|lcccccc|}
\hline Variable & Observations & Mean & Median & Std.Dev. & Min & Max \\
\hline ice & 20116 & 10.97 & 8.56 & 8.27 & 1.03 & 47.85 \\
DA & 20116 & 0.02 & 0.01 & 1 & -3.49 & 3.69 \\
SD & 20116 & 0.6 & 0.51 & 0.34 & 0.17 & 2.18 \\
MB & 20116 & 1 & 0.73 & 0.86 & 0.1 & 5.2 \\
Age & 20116 & 2.15 & 2.2 & 0.56 & 1.1 & 3.22 \\
NI & 20116 & 0.29 & 0.21 & 0.51 & -1.29 & 2.24 \\
Growth & 20116 & 0.32 & 0 & 0.47 & 0 & 1 \\
Mature & 20116 & 0.34 & 0 & 0.48 & 0 & 1 \\
Decline & 20116 & 0.07 & 0 & 0.25 & 0 & 1 \\
Shakeout & 20116 & 0.14 & 0 & 0.35 & 0 & 1 \\
\hline
\end{tabular}

\subsection{Regression Analysis}

Table 2 reports the results of Hypothesis 1: the first column in the table shows the results of the full sample regression where the $\mathrm{DA} * \mathrm{SD}$ coefficients are our concern and represent the relationship between DA and Price as SD rises. The coefficient of DA*SD is -0.495 , and is significantly negative at the $1 \%$ level. Indicating that as the strategy deviates from the conventional level of the industry, the correlation between discretionary accruals and stock price declines. In addition, we divide the sample into two groups, with $\mathrm{HSD}=1$, indicating a higher degree of enterprise disparity, and $\mathrm{HSD}=0$, indicating a lower strategic difference group, in which the coefficient of DA is our most concern. The second and third columns of Table 2 show the sub-sample regression results. The results showed that, although the coefficients of both groups is significantly negative, the coefficients in the high-strategy difference group is smaller and the significance level is higher, and the coefficient difference significance test showed that the coefficient of the two groups is significantly different at the $1 \%$ level. In a nutshell, the results in columns 2 and 3 of Table 2 are consistent with the first column, indicating a strong negative correlation between discretionary accruals and stock prices in the sample groups with high strategic differences. 
From the perspective of control variables, Eps is positively correlated with the stock price, which is in agreement with the existing research results. In short, the above results show that firms with a larger strategic difference, their discretionary accruals and stock prices are negatively correlated, that is, firms with extreme strategic models, the earnings management of which belongs to opportunistic earnings management.

TABLE 2. HYPOTHESIS 1 TEST RESULTS.

\begin{tabular}{|c|c|c|c|}
\hline Variables & $\begin{array}{c}\text { Full sample } \\
\text { Price }\end{array}$ & $\begin{array}{c}\text { HSD=1 } \\
\text { Price }\end{array}$ & $\begin{array}{c}\text { HSD }=0 \\
\text { Price }\end{array}$ \\
\hline $\mathrm{DA}$ & $\begin{array}{l}-0.002 \\
(-0.02)\end{array}$ & $\begin{array}{c}-0.412^{* * *} \\
(-5.86)\end{array}$ & $\begin{array}{l}-0.145^{*} \\
(-1.92)\end{array}$ \\
\hline $\mathrm{DA} \times \mathrm{SD}$ & $\begin{array}{c}-0.495^{* * *} \\
(-3.45)\end{array}$ & & \\
\hline SD & $\begin{array}{l}1.205^{* * *} \\
(5.64)\end{array}$ & $\begin{array}{c}0.850^{* * *} \\
(3.18)\end{array}$ & $\begin{array}{c}2.534^{* * *} \\
(3.36)\end{array}$ \\
\hline MB & $\begin{array}{l}-2.151^{* * *} \\
(-22.06)\end{array}$ & $\begin{array}{l}-1.868^{* * *} \\
(-15.79)\end{array}$ & $\begin{array}{l}-2.804^{* * *} \\
(-21.22)\end{array}$ \\
\hline Age & $\begin{array}{l}-1.856^{* * *} \\
(-10.43)\end{array}$ & $\begin{array}{l}-2.438^{* * *} \\
(-12.22)\end{array}$ & $\begin{array}{c}-1.354^{* * *} \\
(-8.10)\end{array}$ \\
\hline Eps & $\begin{array}{l}7.655^{* * *} \\
(31.14)\end{array}$ & $\begin{array}{l}7.291^{* * *} \\
(24.80)\end{array}$ & $\begin{array}{l}8.399^{* * *} \\
(29.85)\end{array}$ \\
\hline Growth & $\begin{array}{c}-0.496^{* * *} \\
(-3.08)\end{array}$ & $\begin{array}{c}-0.775^{* * *} \\
(-3.52)\end{array}$ & $\begin{array}{c}-0.250 \\
(-1.30)\end{array}$ \\
\hline Mature & $\begin{array}{c}-1.097^{* * *} \\
(-6.42)\end{array}$ & $\begin{array}{c}-1.223^{* * *} \\
(-5.27)\end{array}$ & $\begin{array}{c}-1.075^{* * *} \\
(-5.47)\end{array}$ \\
\hline Decline & $\begin{array}{c}-1.368^{* * *} \\
(-6.93)\end{array}$ & $\begin{array}{c}-1.536^{* * *} \\
(-5.88)\end{array}$ & $\begin{array}{c}-0.967^{* * *} \\
(-3.76)\end{array}$ \\
\hline Shakeout & $\begin{array}{c}-1.344^{* * *} \\
(-7.62)\end{array}$ & $\begin{array}{c}-1.425^{* * *} \\
(-5.97)\end{array}$ & $\begin{array}{c}-1.247^{* * *} \\
(-5.95)\end{array}$ \\
\hline Constant term & $\begin{array}{c}12.392^{* * *} \\
(19.41)\end{array}$ & $\begin{array}{c}19.003^{* * *} \\
(27.82)\end{array}$ & $\begin{array}{c}16.226^{* * *} \\
(17.85)\end{array}$ \\
\hline $\begin{array}{l}N \\
\text { adj. } R^{2} \\
\text { F }\end{array}$ & $\begin{array}{c}17407 \\
0.551 \\
164.633\end{array}$ & $\begin{array}{c}10005 \\
0.536 \\
112.751\end{array}$ & $\begin{array}{c}10111 \\
0.579 \\
113.014\end{array}$ \\
\hline \multicolumn{4}{|c|}{ DA coefficient difference significance test } \\
\hline $\begin{array}{l}\text { chi2 } \\
\text { Prob>chi2 }\end{array}$ & & & \\
\hline
\end{tabular}

Notes: $*, * *, * * *$ significant at the $\leqslant 10 \%, \leqslant 5 \%, \leqslant 1 \%$ levels, respectively.

\section{Conclusion}

We examine the impact of firm strategic differences on value relevance of earnings management and stock-market crash risk. It is found that the value relevance of the discretionary accruals of firms with extreme strategic models is low and the risk of stock price collapse is high. In control of the company's financial situation, growth, listing age and stock liquidity and other characteristics of the company, the conclusion is still established. This suggests that strategic differentiation leads to opportunistic earnings management.

Our conclusion has important practical significance for the accounting information users such as the supervision department and the auditor as well as the investors. First, our conclusion further suggests that 
strategic differences may lead to opportunistic earnings management rather than signaled earnings management. First, our conclusion further suggests that strategic differences may lead to opportunistic earnings management rather than signaled earnings management. Therefore, for the extreme strategic model of the enterprise, auditors in the audit opinion issued should be more cautious. Regulatory departments should increase supervision. Second, it is difficult for investors to determine the performance of firms with extreme strategic models, and the probability of earnings management being found to be low. For such enterprises, investors should read the financial report more carefully, do more analysis, cannot blindly believe in their financial reports, performance information.

\section{References}

[1] Subramanyam, K.R.: Journal of Accounting and Economics 22(1996), p.249

[2] Bentley K A, Omer T C, Sharp N Y: Contemporary Accounting Research 30(2013), p.780

[3] Louis H, Robinson D: SSRN Electronic Journal 39(2003), p.361

[4] Teoh, S.H., I. Welch and T.J. Wong: The Journal of Finance 18(1998), p.1935

[5] Francis J, Lafond R, Olsson P, et al: Journal of Accounting \& Economics 39(2005), p.295

[6] Bowen, R.M., S. Rajgopal and M. Venkatachalam: Contemporary Accounting Research 25(2008), p.351

[7] Carpenter J N: Journal of Finance 55(2000), p.2311

[8] Baginski S P, Hassell J M, Kimbrough M D. T: The Accounting Review 77(2002), p.25 